Online: http://journal.uny.ac.id/index.php/jppfa

\title{
MODAL SOSIAL DAN MEDIA SOSIAL PADA MASYARAKAT CYBER DI DESA MELUNG, KABUPATEN BANYUMAS
}

Imam Malik, Siti Irene Astuti Dwiningrum

Prodi Pend. Imu Pengetahuan Sosial PPS UNY, Universitas Negeri Yogyakarta imammalik07@gmail.com, siti_ireneast@uny.ac.id

\begin{abstract}
Abstrak
Penelitian ini bertujuan untuk mendeskripsikan: (1) penggunaan media sosial, (2) memetakan modal sosial, dan (3) menganalisis peran modal sosial dalam membentuk pola penggunaan media sosial yang ada pada masyarakat cyber di desa Melung. Penelitian ini menggunakan pendekatan kualitatif dengan kajian fenomenologi. Unit analisisnya adalah masyarakat desa Melung. Data primer diperoleh dari hasil wawancara terhadap berbagai kategori informan di desa Melung. Analisis data dilakukan dengan mengumpulkan data, mereduksi data, dan verifikasi yang dilakukan secara bertahap. Hasil penelitian menunjukan bahwa media sosial di desa Melung digunakan sebagai media promosi bagi masyarakat untuk mempromosikan desa mereka sebagai desa wisata. Keberadaan media sosial dan pemanfaatanya sebagai media promosi didukung oleh kepercayaan masyarakat terhadap kepala desa. Kpercayaan masyarakat terhadap kepala desa berperan sebagai modal sosial yang ada di desa Melung. Keberadaan modal sosial yang dimiliki oleh masyarakat berperan sebagai pembentuk masyarakat cyber dan juga faktor utama terealisasinya pembangunan jaringan interenet di desa Melung.
\end{abstract}

Kata kunci: media sosial, masyarakat cyber, modal sosial

\section{SOCIAL CAPITAL AND SOCIAL MEDIA IN CYBER SOCIETY IN THE MELUNG VILLAGE, REGENCY OF BANYUMAS}

\author{
Imam Malik, Siti Irene Astuti Dwiningrum \\ Prodi Pend. Imu Pengetahuan Sosial PPS UNY, Universitas Negeri Yogyakarta \\ imammalik07@gmail.com, siti_ireneast@uny.ac.id
}

\begin{abstract}
This study aims to describe: (1) the use of social media, (2) mapping social capital, and (3) analyzing the role of social capital in shaping the patterns of using social media that exist in the cyber community in Melung village. This research used qualitative approach with phenomenology study. The unit of analysis is Melung village society. Primary data were obtained from interview on various categories of informants in Melung village. Data analysis was done by collecting data, reducing data, and verification which done in stages. The results showed that social media in Melung village was used as a media campaign for the community to promote their village as a tourist village. The existence of social media and their use was supported by the public's trust in the village head. The public's trust in the village head served as a social capital in the village Melung. The role of social capital that exists was as reinforcement in shaping the cyber community and the main factor of the realization, construction of the interenet network in the Melung village.
\end{abstract}

Keywords: social media, cyber society, social capital 


\section{PENDAHULUAN}

Masyarakat cyber merupakan istilah bagi para pengguna internet yang secara aktif melakukan interaksi, transaksi, mencari informasi, ataupun kegiatan lainnya secara online. Stine Gotved menyebutnya dengan istilah Cybersocial Reality yaitu sebuah kehidupan online yang dapat dianalisis dengan pendekatan sosiologi mengenai struktur dan relitas sosialnya (Gotved, 2006, pp. 168-170). Dari pandangan Gotved cybersocial dapat terbentuk dari peran serta individu ataupun kelompok yang melakukan kegiatannya secara terus menerus secara online sehingga membentuk pola, tindakan dan juga pemaknaan terhadap tindaan mereka. Dapat disimpulkan bahwa masyarakat cyber merupakan istilah yang hanya ditunjukan bagi mereka yang aktif melakukan berbagai kegiatan secara online baik hal itu dilakukan secara individu ataupun berkelompok.

Pada dasarnya masyarakat cyber bisa terbentuk karena adanya interaksi yang dilakukan menggunakan perantara perangkat komputer. Saat ini telah tercipta berbagai kategori media interaksi dan komunikasi yang bisa digunakan didalam perangkat komputer. Salah satu media yang ada yaitu menggunakan media sosial. Media sosial merupakan sarana online yang menyediakan berbagai kemudahan untuk melakukan kegiatan komunikasi dan mengakses informasi. Bentuk dari media sosial sendiri bervariasi, masing-masing menawarkan tampilan yang berbeda. Meskipun berbeda tetapi secara umum memiliki unsur yang sama yaitu informasi.

Melihat berbagai isu yang terjadi di masyarakat terkait penggunaan media pada aspek yang negatif tanpa memperhatikan nilai-nilai dan aturan yang telah disepakati di kehidupan sosial maka perlu segera dilakukan pembenahan ataupun upaya pencegahan bagi pengguna baru. Pengunaan media yang keliru tersebut merupakan tindakan yang akhirnya mengarah kepada cyber cryme atau kejahatan cyber. Munculnya tindakan bullying, beredarnya berita hoax, dan bahkan pelecehan seksual yang dilakukan melalui dunia maya atau virtual adalah bagian dari efek penggunaan media sosial dari aspek negatif. Tindakan yang dilakukan dengan dasar perilaku negatif selanjutnya akan merugikan orang lain dan juga diri sendiri.
Salah satu contoh pengunaan media sosial yang tidak tepat dan merugikan diri yaitu pada penggunaan yang berlebihan. Dalam penggunaan sehari-hari media mampu menyediakan berbagai konten yang dapat menarik perhatian penuh dari individu, yang menjadikannya melupakan dunia sosial sebenarnya. Seorang individu dapat mengalami penurunan keterampilan bersosialisasi pada kehidupan nyata karena terlalu berlebihan dalam beraktivitas di dunia virtual hingga akhirnya menimbulkan rasa kesepian secara psikologis pada kehidupan nyata (Junghyun, Robert, \& Wei, 2009, p. 451). Bahkan efek kecanduan terhadap penggunaan media dapat memicu keputusan untuk melakukan bunuh diri oleh seseorang. Strasburger (2012, p. 534) mengatakan bahwa "the media may contribute to adolescent suicide by highlighting such behavior in public cases". Pada kasus lain, media sosial juga bisa dijadikan sebagai alat provokasi, penciptaan isu, dan pemicu konflik, atau bahkan alat politik. Contoh penggunaan media sosial pada ranah politik kasus Arab spring, rakyat menyatukan suara melalui media sosial seperti facebook, twitter dan youtube dalam menyatukan aspirasinya untuk menggulingkan pemerintahan. Selanjutnya terdapat juga pemanfaatan media sosial pada aspek yang positif dalam upaya pembangunan dan peningkatan kualitas sebuah sistem, seperti halnya pemanfaatan youtube sebagai media belajar online atau yang dikenal dengan learning future. Berbagai pihak juga melakukan sosialisasi kebijakan melalui media. Banyak juga kelompok yang memanfaatkan media sosial sebagai sarana diskusi online dalam upaya membuat kegiatan sosial, juga mereka yang memanfaatkan media sosial untuk sarana $e$ commerse atau perdagangan elektronik.

Berbasis data yang ada fungsi dari media sosial akan sangat bergantung pada siapa penggunanya. Nilai-nilai yang termuat di dalam konten media sosial merupakan perangkat nilai yang sengaja diciptakan untuk tujuan khusus, sesuai tujuan dari yang menggunakan. Setiap orang memiliki tujuan yang berbeda dalam perilakunya di kehidupan sosial, termasuk perilaku dalam menggunakan media sosial. Homans memiliki pendapat bahwa perilaku individu dalam mengambil keputusan akan sangat ditentukan oleh nilai-nilai dasar yang membentuk pribadi dari individu yang bersangkutan (Ritzer, 2014, p.715). Dari 
analisis tersebut dapat diindikasikan bahwa terdapat pola sosialisasi tertentu yang dapat memengaruhi bagaimana masyarakat memanfaatkan media sosial, seperti halnya memanfaatkan media sebagai sarana hiburan, sarana peningkatan ekonomi, sarana pendidikan, ataupun sarana politik.

Salah satu pola sosialisasi yaitu sosialisasi yang terjadi atas dorongan dari teman sebaya. Keberadaan teman dalam sebuah komunitas jaringan sosial online menjadikan seorang individu tertarik untuk bergabung di dalam komunitas tersebut (Kuan-Yu \& HsiPeng, 2011, p.3). Pengaruh teman menunjuk pada salah satu pola pembentukan perilaku yaitu bahwa perilaku pengguna media sosial juga terkait dengan perilaku anggota lain dalam komunitas yang sama. Berdasarkan pemaparan tersebut lingkungan menjadi salah satu pertimbangan seseorang dalam mengambil keputusan dan menjadi penunjang terbentuknya pola perilaku penggunaan media sosial.

Pada umumnya pembentuk lingkungan sosial adalah masyarakat yang ada di sekitar kehidupan seorang individu. Pada masyarakat yang kuat lingkungan sosial memegang kendali atas perilaku yang diperbuat oleh anggotanya dan individu menyesuaikan diri terhadap nilai dan tata aturan yang ada pada kelompoknya (Veeger, 1993, p.123). Dengan demikian jika sebuah kelompok masyarakat memiliki keputusan bersama untuk menggunakan sarana baru (media sosial) dalam melakukan kegiatan sosial maka individu akan mengikuti pola yang dibentuk oleh kelompoknya.

Selama ini penggunaan media sosial banyak dilakukan oleh individu yang bahkan tidak merasa menjadi bagian dari masyarakat. Dari penelitian yang dihimpun oleh KEMKOMINFO ditemukan data bahwa pengguna internet sebagian besar adalah kelompok umur remaja, sementara sisanya adalah anak anak dan orang dewasa. Fakta ini menunjukan bahwa orang dewasa sebagai panutan dalam kehidupan sosial dan bermasyarakat tidak dapat mengimbangi kebutuhan pada ranah kehidupan online. Hal ini berarti saat remaja sebagai pengguna media sosial mengakses media sosial dan mereka melakukan berbagai aktifitas, tidak ada pengawasan khusus dari lingkungan sosialnya, dalam hal ini orang dewasa. Keadaan ini bagi remaja dapat menjadi ruang bebas berekspresi tanpa batas, tanpa pengawasan dan pegangan nilai yang tepat. Remaja dengan pengawasan yang kurang juga berpotensi memunculkan tindakan kurang menyenangkan bagi pihak lain.

Untuk dapat memberikan pengawasan yang maksimal terhadap penggunaan media sosial seharusnya masyarakat ikut terlibat sebagai pengguna dan pemerintah turun serta untuk memberikan arahan. Keterlibatan masyarakat tanpa didukung pengetahuan yang tepat tidak akan memberikan efek yang signifikan bagi upaya memaksimalkan fungsi media sosial. Media sosial merupakan hal baru yang perlu dipelajari secara menyeluruh, sehingga setiap pengguna dapat memanfaatkan dengan baik dan mampu menghindari halhal yang berpotensi merugikan. Perlu diingat bahwa kelompok umur remaja merupakan kelompok umur yang memiliki kategori umur produktif, kelompok umur remaja memiliki semangat yang lebih tinggi dibandingkan dengan kelompok umur lain dalam mempelajari hal-hal baru serta memiliki rasa penasaran yang juga lebih tinggi terhadap berbagai hal. Jika tidak diimbangi dengan pengetahuan kelompok orang dewasa tentang internet dan media sosial maka upaya pengawasan tidak bisa berjalan dengan baik, karena remaja lebih tahu dan lebih pandai untuk menghindar dari kesalahan.

Strategi dasar untuk dapat memberikan pengawasan terhadap penggunaan media sosial adalah dengan mengoptimalkan fungsi peran serta masyarakat, yaitu dengan berperan sebagai sesama pengguna media. Peran serta masyarakat dapat dilakukan pada setiap tahap atau proses, seperti tahap perencanaan, pelaksanaan dan pengawasan. Sementara jika proses awal sudah dilewati seperti kebanyakan yang terjadi sekarang ini, yaitu masyarakat telah banyak yang menggunakan internet dan mengakses media sosial maka upaya mengoptimalkan peran serta masyarakat dapat dilakukan pada tahap pengawasan.

Serangkaian upaya proses pembangunan masyarakat cyber dapat didukung dengan mengefektifkan keberadaan modal sosial. Modal sosial memiliki peran dalam membentuk berbagai kehidupan masyarakat, termasuk dalam era masyarakat baru yaitu masyarakat internet. Keberadaan sebuah kelompok, institusi, grup, ataupun sejenisnya seperti masyarakat cyber tidak akan dapat terbangun secara kuat tanpa adanya penopang dari modal sosial (Hasbullah, 2006, p. 37). Modal sosial 
dapat menjadi sarana peningkatan kemampuan (Tohani, 2015, pp. 151-166). Berdasar informasi dari hasil penelitian yang relevan modal sosial berperan sebagai pengorganisasi masa untuk dapat memulihkan diri dari ketidakseimbangan yang terjadi (Dwiningrum, 2014, p. 510), dan sebagai sarana untuk dapat mengembangkan berbagai pengetahuan dan juga sarana organisasi (Wichkramasinghe \& Weliwitigida, 2011, pp. 393-413).

Modal sosial adalah sekumpulan nilai informal atau norma yang menyebar di antara anggoata kelompok yang memungkinkan kerja sama antara mereka (Fukuyama, 1997, pp. 377-378). Kerjasama tersebut terjadi apabila antaranggota kelompok masyarakat saling memenuhi harapan. Modal sosial juga dikatakan sebagai akar dari perubahan yang tersembunyi di balik sesuatu (Rasekhi \& Angadji, 2014, p.12). Sementara itu agar dapat mengoptimalkan peran modal sosial diperlukan sosok pemimpin yang dipercaya dalam sebuah masyarakat (Hanum, 2011, pp. 22-44). Lebih lanjut Fukuyama menjelaskan apabila kondisi ini bertahan pada sebuah masyarakat maka dapat memunculkan potensi peningkatan drajat inovasi masyarakat dan daya adaptasi masyarakat. Parson melihat hubungan antarmanusia sebagai sebuah upaya untuk menjaga kelangsungan hidup sebuah sistem. Sebuah sistem seharusnya memiliki fungsi adaptasi dan kemudian fungsi ini akan berkaitan positif dengan teknologi serta tingkat kemandirian (Narwoko \& Suyanto, 2013, pp. 370-371).

Modal sosial mampu menciptakan kondisi masyarakat yang mendukung bagi berkembangnya lingkungan masyarakat cyber yang positif. Keberadaan modal sosial dalam kehidupan masyarakat dapat menghidupkan kreativitas masyarakat dalam menggunakan media sosial. Modal sosial dapat berfungsi dengan baik tentunya apabila unsur-unsur modal sosial dapat terpenuhi. Tiga unsur pokok, seperti jaringan, norma, pertukaran dan kepercayaan (Chen \& Meng, 2015, p. 2) Keberadaan modal sosial juga dapat berfungsi sebagai pengawas dalam setiap kegiatan yang mungkin dilakukan menggunakan media sosial agar selalu terjaga pada kegiatan-kegiatan yang positif. Selanjutnya modal sosial juga dapat menjadi sarana untuk mempersatukan masyarakat agar memiliki persepsi yang sama untuk menjadikan media sosial berfungsi lebih optimal.
Pada umumnya masyarakat pengguna internet melakukan aktivitas di dunia virtual seperti saat menggunakan media sosial adalah atas inisiatif sendiri. Mereka yang ingin menggunakan media sosial maka harus mencari perangkat sendiri dan mencari jaringan internet sendiri. Dengan demikian tidak ada tanggung jawab moral dan rasa keterikatan oleh masyarakat dalam menggunakan internet terhadap pihak-pihak tertentu. Hal ini berbeda dengan apa yang terjadi pada masyarakat di desa Melung. Desa Melung merupakan sebuah desa yang terletak di lereng sebelah selatan gunung Slamaet, secara administratif berada pada wilayah kecamatan Kedungbanteng, Kabupaten Banyumas, Profinsi Jawa Tengah. Pada masyarakat di desa Melung penggunaan media sosial diawali dari inisiatif pemerintah desa dengan membangun jaringan internet di desa. Selain menyediakan jaringan internet pemerintah desa juga melakukan pelatihan dan pengenalan bagi masyarakat terkait teknologi komputer dan jaringan internet. Saat ini sebagian dari masyarakat desa Melung telah menjadi masyarakt cyber dan aktif di berbagai media sosial. selain masyarakatnya yang aktif pemerintah desa juga komitmen untuk membangun berbagai program terkait keberadaan internet di desa, seperti pembangunan pasar online pembangunan website desa yang terintegrasi dengan informasi desa, juga pembentukan grup facebook desa yang dapat mengakomodir upaya interaksi seluruh masyarakat desa.

Upaya pembentukan masyarakat cyber yang dilakukan oleh desa, seharusnya modal sosial ditempatkan pada setiap prosesnya, mulai dari perencanaan, pembangunan hingga pengawasan. Jika implementasi modal sosial dalam pembangunan masyaraat cyber dilakukan pada setiap aspek seharusnya keberadaan masyarakat cyber desa Melung adalah contoh ideal dari keberadaan masyarakat cyber di tempat lain. Dengan begitu, desa Melung dapat menjadi contoh bagi semua pihak yang ingin mengoptimalkan fungsi internet dan media sosial. Khususnya mengoptimalkan fungsi media sosial pada ranah kelompok.

Berdasarkan paparan diatas peneliti tertarik untuk melakukan penelitian terhadap dukungan keberadaan modal sosial di desa Melung terhadap pola penggunaan media sosial yang dilakukan oleh masyarakat cyber di desa tersebut. Pentingnya penelitian ini dilakukan agar dapat memberikan gambaran ten- 
tang pola penggunaan media sosial yang berasal dari bentukan komunitas, yaitu masyarakat desa Melung itu sendiri. Selain itu penting juga untuk dapat menunjukan lebih detail tentang peran modal sosial dalam proses pembentukan masyarakat cyber yang ada di desa Melung.

Pada upaya pembangunan jaringan internet di desa Melung telah terlihat adanya keterlibatan unsur modal sosial. Hasil prasurvei menunjukan bahwa ada proses yang tidak tersampaikan dengan baik dalam pembangunan masyarakat cyber di desa Melung, khususnya proses sosialisasi dan pengawasan. Peneliti melakukan identifikasi untuk dapat mengetahui bagian-bagain yang perlu di evaluasi dalam pelaksanaan internet di desa serta dapat memberikan masukan agar keberadaan internet desa dapat dikembangkan menjadi investasi yang dapat berperan besar dalam pembangunan desa.

\section{METODE PENELITIAN}

Penelitian ini menggunakan pendekatan kualitatif, dalam hal ini adalah fenomenologi. Penelitian ini diharapkan dapat mengambil data sekaya mungkin, oleh karena itu teknik pengumpulan data digunakan dengan wawancara mendalam.

Penelitian ini dilakukan di desa Melung, kecamatan Kedungbanteng, kabupaten Banyumas. Desa Melung mempunyai 2 dusun yang terdiri atas 4 grumbul. Desa Melung adalah sebuah desa yang hampir pada seluruh wilayahnya tersedia jaringan internet meskipun secara administrasi wilayah desa Melung merupakan wilayah yang terletak di pedalaman. Penelitian di desa Melung dilakukan dari bulan Oktober 2016 hingga Maret 2017.

Subjek penelitian ini adalah pemimpin masyarakat, dalam hal ini adalah kepala desa. Di samping itu informasi juga diambil dari masyarakat yang mengerti tentang asal mula pembangunan internet di desa dan yang dianggap dapat memberi informasi yang akurat, dalam hal ini informan ditentukan dengan teknik snowball sampling dan purposive sampling.

Upaya pengumpulan data dilakukan dengan teknik deep-interview dengan wawancara semi terstruktur. Teknik observasi digunakan untuk mengamati kebudayaan dan kegiatan sehari-hari masyarakat di desa Melung disamping dokumen-dokumen yang dapat dijadikan data penunjang yang penting untuk kesempurnaan data yang digali.

Untuk menjamin keabsahan data digunakan teknik triangulasi data, yaitu teknik yang digunakan untuk mengkonfirmasi pernyataan antarinforman, juga membandingkan hasil wawancara dengan hasil observasi serta memperpanjang waktu penelitian di lapangan.

Analisis data dilakukan dengan teknik deskriptif, merupakan penggambaran dari data yang diperoleh, kemudian dianalisis dianalisis dalam bentuk kata untuk memperolah gambaran makna dan kesimpulan. Proses untuk melakukan analisis data deskriptif dilakukan menggunakan model analisis data interaktif dari Miles dan Huberman. Proses analisis yang dilakukan berdasar metode ini diselesaikan melalui 4 tahap, yaitu: (1) pengumpulan data, (2) reduksi data, dan (4) penarikan kesimpulan. Tahap-tahap tersebuat dilakukan sebagai proses yang saling berkaitan dan interaktif.

\section{HASIL PENELITIAN DAN PEMBAHASAN}

Paparan hasil penelitian berikut akan disajikan meliputi (1) Deskripsi penggunaan media sosial di desa Melung (2) deskripsi keberadaan modal sosial di desa Melung (3) peran modal sosial dalam pembentukan pola penggunaan media sosial pada masyarakat cyber di desa Melung.

Dari penelitian yang dilakukan diperoleh informasi bahwa penggunaan media sosial di masyarakat desa Melung lebih cenderung kepada fungsi promosi. Masyarakat desa Melung menjadikan media sosial sebagai sarana untuk mempromosikan desa, untuk mngenalkan desa Melung sebagai desa wisata. Sementara itu ide utama pemanfaatan media sosial sebagai media promosi adalah berkat peran kepala desa sebagai inisiator yang dilakkukan oleh mantan kepala desa saat dia sedang menempati jabatan sebagai kepla desa. Untuk dapat mengetahui peran modal sosial dalam penggunaan modal sosial maka terlebih dahulu perlu diketahui media sosial yang digunakan dan modal sosial apa yang berperan.

\section{Penggunaan Media Sosial oleh Masyarakat Cyber di Desa Melung}

Penggunaan media sosial muncul sebagai wujud pemanfaatan jaringan internet yang disediakan desa. Sejak masuknya inter- 
net di desa keberadaan media telah menjadi daya tarik yang besar bagi sebagian penduduk desa terutama generasi muda dan anak-anak. Khususnya dalam penggunaan media kelompok usia remaja menunjukan ketertarikan yang lebih besar (Teo, 2001, pp. 125-137).

Saat ini sebagian besar penduduk desa telah memiliki akun media sosial facebook dan mereka semua tergabung ke dalam grup facebook desa. Selain facebook masyarakat desa juga mengenal youtube. Apapun nama medianya, media sosial memiliki berbagai fungsi, seperti jaringan, informasi, interaksi, arsip, konten, juga penyebaran. Pada penggunaan media sosial di desa Melung fungsifungsi media sosial tersebut dimanfaatkan sesuai karakteristik masyarakat desa Melung.

\section{Funngsi Jaringan}

Peran jaringan yang dimasksud dalam penggunaan media sosial adalah jaringan dalam pemahaman teknologi komputer dan juga jaringan dalam pemahaman hubungan antarkhalayak media atau pengguna media. Penggunaan media tidak dapat dilakukan tanpa adanya jaringan yang dapat digunakan. Jaringan pada penggunaan media layaknya jalan raya yang bisa di lewati kendaraan, saat jaringan terputus maka interaksi juga terhalang. Begitu juga penggunaan media tidak dapat berjalan tanpa adanya hubungan antarjaringan. Koneksi atau hubungan digunakan untuk melakukan interaksi dan pemindahan informasi data antarjaringan.

Pembentukan jaringan sosial di desa Melung terbentuk atas ikatan letak geografis yang sama, yaitu sebagai warga desa Melung. Ikatan ini oleh Blanchard disebut sebagai ikatan virtual tradisional yang juga menurut Blanchard ikatan ini mampu mendukung keberadaan modal sosial. Sehingga jelas disampaikan bahwa titik-titik jaringan di desa Melung adalah seluruh anggota masyarakat. Titik-titik jaringan yang telah ada kemudian diperkuat oleh media. Pada masyarakat desa melung tidak semua individu menggunakan media sosial, sehingga tidak semua dapat tergabung dalam jaringan yang baru melalui media sosial, ada kelompok baru yang terbentuk dengan ikatan semakin kuat da nada kelompok lain yang tidak mengikuti perkembangan.

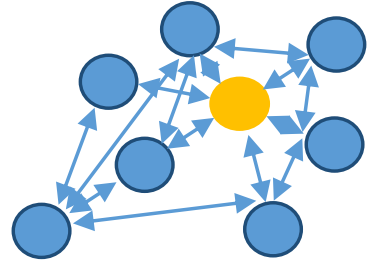

.$A$

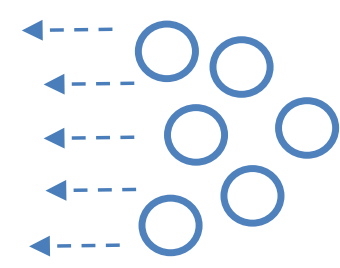

. B
Gambar 1. Seketsa Bentuk Jaringan Masyarakat di Desa Melung

Gambar A. seketsa jaringan untuk masyarakat pengguna media sosial. Gambar B seketsa untuk masyarakat yang tidak menggunakan media sosial. Keberadaan jaringan didukung oleh adanya perangkat media sosial. Media sosial membantu menghubungkan titiktitik jaringan yang telah terbentuk, yaitu menghubungkan antarindividu dengan individu dan antarindividu menjadi sebuah kelompok. Mereka yang menggunakan media sosial di desa Melung memiliki banyak keuntungan, diantaranya: komunikasi lebih terbuka dengan kepala desa dan pemerintah desa, akses informasi desa lebih mudah didapatkan, lebih up to date terhadap hal-hal baru khususnya hal baru yang dikeluarkan oleh desa, mempunyai banyak kesempatan untuk memperkuat jaringan lama dan membuat jaringan yang baru antarpenduduk desa.

Berdasarkan hasil olah data yang dilakukan diketahui bahwa keberadaan jaringan dari aspek teknis yang ada di desa Melung berada pada kategori lemah. Dengan jumlah pengguna yang semakin bertambah, keberadaan jaringan internet di desa belum pernah di tingkatkan dari segi kualitasnya. Keadaan ini menjadikan akses internet gratis yang disediakan desa tidak bisa berperan maksimal untuk digunakan. Akibat akses jaringan yang lemah masyarakat cyber tidak memiliki dukungan yang kuat untuk dapat mengambangkan potensi sebagai masyarakat cyber. Seorang individu tidak bisa melihat video dengan baik jika jaringan yang dimiliki lemah, seorang pengguna informasi tidak dapat mengakses informasi dengan baik jika jaringan internet yang dimiliki lemah. Selain itu dari segi mental masyarakat desa keberadaan jaringan yang lemah tidak bisa memberikan dorongan semangat untuk masyarakat desa menggunakan internet. 


\section{Informasi}

Informasi merupakan komoditi dalam masyarakat informasi (Nasrulah, 2016, p. 19). Pengguna media merepresentasikan identitasnya, memproduksi konten dan melakukan interaksi berdasarkan informasi. Bagi masyarakat di desa Melung informasi adalah bagian yang tidak dapat mereka lewatkan, terutama mereka yang memang aktif dalam menggunakan media sosial seperti facebook dan twitter.

Masyarakat desa Melung menjadi penikmat informasi berdasarkan karakteristik setiap individu. Ada sebagian dari masyarakat yang berperan sebagai pelajar, ada yang berperan sebagai petani, dan ada juga yang berperan sebagai pegawai desa, serta berbagai peran lainnya. Bagi pemuda desa khususnya yang masih berstatus sebagai pelajar mereka banyak menggunakan media sosial untuk mengakses informasi terkait bahan-bahan yang dibutuhkan untuk mengerjakan tugas. Bagi pemerintah desa media sosial digunakan sebagai sarana mendapatkan informasi terkait berbagai persoalan desa dan pemerintahan. Bagi para petani informasi yang dicari adalah tentang pertanian. Semua pihak dengan keperluannya masing-masing dapat dipenuhi dengan adanya informasi dari media sosial.

Lebih jauh membahas informasi yang ada di desa Melung menurut Castells (Nasrulah, 2016, p. 19) terdapat karakteristik dari informasi dan kehadiran teknologi informasi, yaitu: Informasi merupakan bahan baku ekonomi, karakteristik ini disadari oleh penggagas internet desa yang juga merupakan pelaksana program internet desa. Dengan adanya informasi, pengetahuan dapat tercipta dan dengan pengetahuan yang dimiliki gairah ekonomi juga semakin meningkat. Petani yang mengetahui harga hasil panennya mahal menjadi semakin giat untuk meningkatkan produksinya. Pedagang yang mengetahui adanya informasi tentang barang-barang terbaru yang bisa dijual menjadi semakin bersemangat untuk meningkatkan usahanya. Meskipun tidak bisa disampaikan berdampak secra langsung tetapi keberadaan teknologi informasi di desa Melung sangat membantu pemerintah dalam menggerakkan roda perekonomian warga desa.

Teknologi informasi memberikan pengaruh kepada masyarakat maupun individu, dimulai dari perubahan individu dan mengarah kepada perubahan pada level masyarakat.
Keberadaan media sebagai bagian dari teknologi informasi akan mempermudah dalam usaha pengelolaan informasi yang memungkinkan logika jaringan diterapkan dalam institusi maupun proses ekonomi. Pemerintahan desa Melung mengimplementasikan karakteristik ini dalam bentuk pembangunan pasar online. Selama keberadaan media informasi tetap eksis maka pasar online pun tetap menjadi pilihan.

Karakteristik berikutnya menunjukan bahwa ketika teknologi informasi dan sistem jaringan diterapkan pada kehidupan masyarakat maka akan muncul fleksibilitas yang lebih besar, dengan konsekuensi bahwa proses organisasi dan lembaga ekonomi dengan mudah dibentuk dan terus menerus diciptakan (Narwoko \& Suyanto, 2013, p. 402). Pada masyarakat desa Melung proses ini mulai terbentuk meskipun dalam intensitas yang lambat, pembangunan pasar online merupakan sesuatu yang baru dan belum dipahami oleh seluruh masyarakat. Saat ini pasar online di desa Melung masih dalam tahap pengenalan. Saat masyarakat memahami terhadap hal yang menjadi tujuan dari adanya pasar online mereka juga akan menyadari kemudahan-kemudahan yang dapat diterima.

\section{Interaksi}

Interaksi merupakan bagian utama dari fungsi media baru. Media sosial memungkinkan setiap orang untuk berbagi pendapat dan saling berargumen. Pada masyarakat desa Melung media yang familiar digunakan adalah facebook. Proses interaski terjadi saat informasi disampaikan sebagai suatu posting-an di grup facebook ataupun di akun pribadi setiap individu. Seperti yang telah dibahas pada bagian fungsi informasi, munculnya interaksi sering kali dipicu oleh adanya informasi yang dibagikan oleh seseorang di media sosial. Bagi pengguna media sosial informasi merupakan bahan diskusi yang menarik, begitu juga pada pengguna media sosial pada masyaraat di desa Melung. Keberadaan grup facebook menjadi lebih ramai dengan adanya interaksi yang di awali oleh adanya komentar terhadap informasi yang diposting oleh salah seorang anggota grup.

Terdapat dua tipologi untuk menggambarkan tipe interaski yang terjadi melalui media sosial, yaitu terbuka dan tertutup. Pada tipe terbuka pengguna memiliki kesempatan 
untuk menentukan bagaimana jariangan ini akan dibentuk dan bagaimana interaski itu terjadi. Sementara pada tipe tertutup khalayak media disajikan pilihan-pilihan selayaknya jalan yang pada setiap arah akan membawa ke arah tujuan yang berbeda. Kondisi ini dapat ditemui saat khalayak media memutuskan untuk mengakses media baru. Media mana yang ia pilih akan membawanya kearah yang telah ditentukan (Nasrulah, 2006, p. 27). Pada masyarakat desa Melung penggunaan tipe interaksi yang terjalin dilakukan antarsesama penduduk desa dan arah penggunaan media sosial yang dilakukan adalah untuk memperkuat interaksi serta melakukan promosi untuk desa.

\section{Simulasi}

Simulasi menawarkan pengguna media sosial suatu kondisi layaknya pada realitas kehidupan sehari-hari. Melalui simulasi terjadi proses saling menyapa, berinteraksi, dan juga saling berbagi. Keberadaan media dianggap tidak lagi mewakili realitas, tetapi sudah merupakan realitas tersendiri, bahkan apa yang ada di media lebih nyata dari realitas itu sendiri (Nasrulah, 2006, p. 29). Hal ini tidak berlaku pada pengguna media sosial di desa Melung, kedudukan media adalah mewakili realitas. Masyarakat desa Melung lebih banyak hidup pada realitas sosial dibandingkan dengan media. Meskipun beberapa pengguna telah menjadikan media sosial sebagai pendukung dari realitas itu sendiri. Sementara sebagian besar yang lain masih bertahan dengan relaitas sebenarnya tanpa intervensi dari media, karena faktor akses yang terbatas terhadap media dan pemahaman yang terbatas terhadap media.

Bagi sebagaian dari masyarakat desa yang paham terhadap media, fungsi simulasi dijadikan sebagai sarana untuk mencitrakan keadaan desa kepada masyarakat luas. Saat orang melakukan pencarian dengan kata kunci "Desa Melung" di internet maka akan muncul banyak sekali citra tentang desa Melung sebagai desa Cyber. Konten media yang ditemukan adalah simulasi dari keadaan desa yang berusaha disampaikan oleh masyarakat desa Melung kepada khalayak media secara luas.

Konten

Pembuatan konten media sosial oleh masyarakat desa adalah konten dengan tema desa Melung. Konten yang dimaksud merupakan konten promosi. Konten promosi berisi informasi tentang desa yang dikemas dengan menarik untuk menarik pendatang agar berkunjung ke desa Melung. Saat ini desa Melung adalah desa yang sedang merintis sebagai desa wisata sehingga upaya promosi memang perlu dilakukan.

Konten media dengan tujuan promosi adalah sebagian dari konten yang diproduksi oleh masyarakat desa, karena tidak semua masyarakat desa pengguna media sosial memproduksi konten yang dimaksud. Konten yang umum diproduksi selain konten promosi adalah konten tentang keseharian masyarakat atau yang lebih dikenal dengan sebutan "status". Selain itu konten konten yang juga diproduksi adalah konten terkait informasi tentang desa yang ditunjukan kepada anggota grup desa, seperti konten yang dibuat oleh ketua pkk untuk para angggotanya, ataupun konten yang dibuat oleh ketua karangtaruna yang ditujukan kepada para pemuda.

\section{Keberadaan Modal Sosial pada Masyarakat di Desa Melung}

Menurut Hasbullah terdapat unsurunsur di dalam masyarakat seperti, jaringan, trust, norma-norma, resiprocity, yang dapat digunakan untuk mencapai kemajuan bersama (Hasbullah, 2006, pp. 3-14). Pada masyarakat desa Melung kemajuan kehidupan di desa mulai bisa dirasakan sejak mulai intensifnya pembangunan sarana dan prasarana desa, seperti pembangunan gedung sekolah, pembangunan jalan, dan pembangunan jaringan informasi.

Terlaksananya berbagai pembangunan secara besar-besaran yang ada di desa Melung tidak lepas dari peran kepala desa. Berdasarkan analisis modal sosial dari Hasbullah, kemajuan yang dialami oleh masyarakat adalah buah dari kerja keras masyarakat itu sendiri yang memanfaatkan berbagai potensi sumber daya sosial yang ada di dalamnya. Diperkuat dengan asumsi dari Francis Fukuyama bahwa trust adalah bagian terpenting dari modal sosial, atau sumber utama yang akan menentukan modal sosial akan kuat atau lemah (Fukuyama, 2010, pp. 41-44). Jika melihat keberhasilan pembangunan oleh masyarkat desa Melung terhadap kehidupan mereka, maka dapat diasumsikan adanya trust 
yang kuat sebagai modal sosial yang dimiliki penduduk desa Melung dalam kehidupan sosial masyarakat. Trus yang dimaksud yaitu kepercayaan masyarakat terhadap kepala desa untuk melakukan perubahan melalui berbagai upaya pembangunan di desa. Beberapa analisis tentang keberadaan modal sosial di desa Melung antara lain:

\section{Kepercayaan Masyarakat terhadap Kepala} Desa

Dari pemaparan data diatas, ditemukan bahwa trust atau rasa percaya yang tiggi dimiliki oleh masyarakat desa terhadap kepala desa dan pemerintahannya. Trust terlihat saat kepala desa yang merupakan pendatang dari luar desa terpilih. Selain percaya saat memilih kepala desa yang merupakaan pendatang, masyarakat desa Melung juga percaya terhadap berbagai kebijakan yang diambil oleh kepala desa terpilih. Berbagai kebijakan berjalan dengan tanpa kendala dari internal masyarakat desa. Pembangunan sarana jaringan internet adalah hal baru yang tidak dimengerti oleh kebanyakan masyarakat desa dan bahkan desa lain belum melakukanny, tetapi pembangunan ini tetap bisa berjalan tanpa ada perlawanan dari warga.

Kepercayaan yang besar warga desa terhadap kepala desa adalah faktor utama keberhasilan pembangunan desa hingga saat ini. Sejak tahun 2002 hingga tahun 2017, desa Melung telah mampu membangun gedung sekolah SMP, sarana PAUD, akses jaringan internet gratis kepada seluruh warga dan juga membangun nama desa sebagai desa pelopor dan desa mandiri. Selain sarana fisik pembangunan juga berhasil pada sektor sumber daya manusia, yaitu dengan meningkatkan mental dan pengetahuan masyarakat.

\section{Jaringan}

Jaringan sosial pada masyarakat desa Melung terbentuk antarpenduduk desa. Sebagai masyarakat yang memiliki latar belakang lingkungan serba terbatas tidak banyak upaya yang bisa dilakukan dengan masyarakat dari luar desa, termasuk untuk membangun jaringan. Masyarakat yang sebagian besar adalah petani dan penggarap ladang tidak memiliki banyak kesempatan untuk melakukan pertukaran dengan dunia luar, terutama dengan keterbatasan pendidikan yang dimilikinya. Se- belum pemerintahan desa periode 2002-2008, sebagian besar masyarakat desa Melung adalah lulusan sekolah dasar. Hal ini juga menjadi kendala untuk terciptanya jaringan sosial penduduk desa dengan penduduk luar desa, karena lingkungan pergaulan penduduk desa yang juga sempit.

Berdasarkan data yang telah dipaparkan pada bagian display data, diketahui bahwa sumber jaringan yang ada di desa Melung berasal dari kepala desa. Kepala desa berperan sebagai seorang tokoh yang memiliki jaringan sosial luas dibandingkan masyarakat desa. Dengan jaringan yang dimiliki, kepala desa memegang posisi penting dalam setiap program pembangunan desa, yaitu sebagai pencetus ide dan sebagai pelaksana pembangunan.

Contoh suksesnya pembangunan jaringan internet di desa Melung karena adanya dukungan dan kerjasama antara kepala desa dengan pihak yang mengerti mengenai internet. Jaringan sosial yang dimiliki kepala desa berperan penting dalam mengimplementasikan internet di desa Melung, seperti sebagai pemberi saran atau ide, sebagai penyedia alat, dan sebagai pengelolaan jaringan pasca terpasangnya internet di desa. Saat ini kepemimpinan kepala desa telah berubah, tetapi jaringan yang ada tidak terputus, hal ini dikarenakan pelaksana program internet desa tetap memilik posisi sebagai pengelola berbagai kegiatan desa. Dengan adanya pembangunan akses internet, desa Melung telah lengkap mendapat predikat sebagai desa yang progresif dalam melakukan pembangunan.

Saat ini keberadaan jaringan di desa Melung semakin melebar dengan dikenalnya desa Melung sebagai desa internet dan desa pelopor masuknya internet desa. Pemerintah melalui kementrian informasi mendukung gerakan internet desa yang ada di desa Melung dengan memberikan bantuan beberapa perangkat komputer untuk kegiatan platihan internet di desa. Dengan adanya pengakuan dari pemerintah, sekaligus menjadi tanda bahwa desa Melung telah mendapat jaringan baru melalui bentuk kepercayaan yang diberikan oleh pemerintah. Selain pemerintah banyak pihak yang secara personal datang ke desa Melung, terutama kaum akademisi yang ingin melakukan kajian ataupun penelitian. Keadaan ini menjadikan desa Melung semakin kuat dengan jaringan yang dimilikinya. 


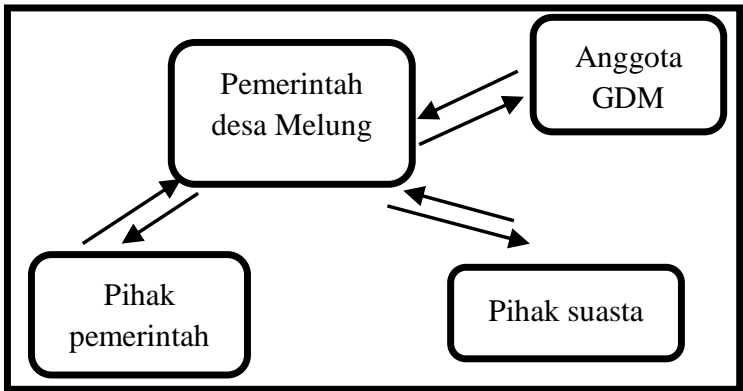

Gambar 2. Pola Jaringan Pemerintah desa Melung

Sikap Peduli Masyarakat terhadap Lingkungan

Berdasarkan olah data yang telah dilakukan diketahui bahwa masyarakat desa Melung memiliki beberapa kategori tindakan yang menunjukan sikap peduli sebagai suatu modal sosial dalam kehidupan sehari hari. Sikap peduli merupakan tindakan yang menunjukkan adanya rasa saling memiliki antarmasyarakat dan antara masyarakat dengan pemerintah desa. Sikap peduli oleh masyarakat desa selanjutnya berkembang menjadi tindakan proaktif. Dalam teori modal sosial tindakan proaktif perlu dimiliki oleh anggota komunitas untuk turut serta membangun komunitas tersebut (Hasbullah, 2006, p. 16). Partisipasi dalam membangun komunitas juga terjadi pada masyarakat di desa Melung, meskipun masyarakat mendukung sepenuhnya pembangunan yang dilakukan oleh pemerintah, tetapi dalam perjalannanya pengawasan dari masyarakat tetap dilakukan. Berbagai tindakan juga dilakukan untuk mendukung pembangunan yang sedang di lakukan oleh pemerintah desa.

Implementasi nilai dan Norma dalam Kehidupan

Keberadan nilai dan norma di desa Melung merupakan warisan dari filosofi hidup para pendiri desa. Masyarakat desa Melung memiliki kearifan lokal sebagai masyarakat dengan latar belakang pertanian dan alam sebagai sumber penghidupan. Nilai dan norma yang ada meruapakan nilai kehidupan untuk dapat hidup selaras dengan alam. Keberadaan nilai dan norma pada masyarakat di desa Melung saat ini masih terjaga dan masih dapat dilihat dalam kehidupan kehidupan sehari-hari masyarakatnya.

Ketika norma yang efektif terbentuk, norma tersebut menjadi modal sosial yang kuat bagi suatu kelompok (Hasbullah, 2006, p.13-14). Norma-norma yang efektif mencegah munculnya kejahatan, hal ini akan menciptakan kebebasan seseorang dalam beraktivitas sehari-hari. Keberadaan norma di suatu lingkungan sosial mampu menciptakan rasa damai dan ketenangan dalam kehidupan. Pada kasus di desa Melung keberadaan nilai dan norma pada masyarakat dapat dilihat dari adanya sarana fisik seperti batu dan tanaman hias yang berada di tengah sawah. Keberadaan batu yang juga dibarengai dengan tanaman disampingnya merupakan lokasi bagi penempatan sajen yang digunakan sebagai bentuk rasa syukur terhadap alam.

Bentuk pengungkapan rasa syukur yang dilakukan masyarakat desa dengan memberikan sajian di tengah lahan persawahan menunjukan adanya nilai-nilai yang masih dipegang dalam memaknai kehidupan. Bentuk sanksi pada nilai-nilai ini bukanlah sanksi dari sesama manusia, tetapi masyarakat percaya ada sanksi lain yang akan datang kepada mereka jika pelanggaran dilakukan. Kepercayaan ini berisi jika kehidupan dijalankan dengan baik maka alam akan memberikan yang terbaik pula. Begitu juga sebaliknya jika kehidupan dijalankan sembarangan maka alam akan memberikan hukumannya. Bentuk dari keberadaan nilai dan norma pada masyarakat desa Melung juga terlihat dari tingginya sopan santun dan unggah ungguh penduduk desa terhadap sesama terutama terlihat dari cara mereka menyambut tamu. Nilai sendiri merupakan standar perilaku sosial yang menggambarkan tentang baik-buruk dan benar salah, terhadap suatu objek dalam kehidupan masyarakat (Abdulsyani, 2007, p. 51). Termasuk perilaku dalam menyambut tamu adalah objek sehingga perlu,menggunakan tutur bahasa yang sopan dan tertata, meskipun berasal dari latar belakang pendidikan yang rendah.

Meskipun banyak norma dan aturanaturan tidak tertulis, tetapi sanksi-sanksi yang menyertainya beberapa merupakan sanksi yang bisa dipahami bersama dan memiliki konsekuensi nyata. Terjaganya perilaku susila penduduk desa, khususnya para pemuda adalah salah satu norma yang memiliki konsekuensi nyata bagi pelanggarnya. Apabila seorang laki-laki yang membawa perempuan ke rumah, hal ini merupakan perilaku yang tidak dibenarkan di lingkungan masyarakat desa Melung. Keberadaan norma dan sanksi dalam 
kehidupan masyarakat desa merupakan bagian dari upaya untuk menjaga ketenangan dan ketentraman kehudupan di desa, dari segala bentuk gangguan, baik berupa gangguan dari dalam maupun dari luar.

Catatan utama hasil temuan modal sosial di desa Melung adalah: Bahwa modal sosial pada masyarakat desa Melung adalah kepercayaan kepada kepala desa. Kepala desa berperan sebagai volenter dalam berbagai program yang dilakukan, karakteristik modal sosial masyarakat desa Melung merupakan karakteristik modal sosial yang ada pada kelompok lokal tradisional dengan menunjuk seorang dari anggota kelompok sebagai Volunteer. Pada komunitas ini uang bukanlah pegangan, bahan orang termiskin di kelompok bisa memberikan pendapat, termasuk bisa menjadi kepala desa.

Meskipun memiliki karakteristik sendiri sebagai kelompok masyarakat tradisional tetapi kecenderungan tipe modal sosial lain juga terlihat. Saat ini masyarakat desa Melung cenderung bergerak kearah tipologi bridging. Bridging social capital memiliki beberapa prinsip yang membedakannya dengan tipologi modal sosial lain. Prinsip-prinsip bridging social capital sepertihalnya setiap anggota dalam suatu kelompok memiliki hak-hak dan kewajiban yang sama, setiap keputusan kelompok diambil atas dasar kesepakatan bersama anggota kelompok, sementara pemimpin kelompok hanya menjalankan hasil dari keputusan kelompok (Hasbullah, 2006, p. 29). Dari prinsip-prinsip yang ada tipe modal sosial menjembatani menunjuk pada masyarakat yang mengakui kebebasan berbicara setiap individu, mengakui hak asasi manusia, layak untuk dijunjung tinggi dan dihormati. Meskipun modal sosial adalah bagian dari milik komunitas dalam hal ini modal sosial tidak dapat digeneralisasikan pada perilaku individu dimana dia berada (Onyx \& Bullen, 2000, p. 24). Artinya bahwa tidak semua masyarakat di desa Melung berprilaku dan memanfaatkan modal sosial sebagai bagian dari milik bersama.

\section{Peran Modal Sosial pada Masyarakat Cyber Desa Melung dan Perannya dalam Membentuk Pola Penggunaan Media Sosial}

Keberadaan media sosial di desa Melung bisa terlaksana dari adanya kerjasama berbagai pihak, juga karena adanya dukungan dari berbagai pihak. Pihak pihak yang terlibat memegang perannya masing-masing dan memberi dukungan sepenuhnya berdasar kemampuan yang dimiliki. Bagi analisis modal sosial setiap pihak yang terkait memiliki spesifikasi peran dan dukungan yang berbeda.

Trust sebagai Pembentuk Masyarakat Cyber

Modal sosial yang ada di desa Melung adalah kepercayaan masyarakat terhadap kepala desa. Kepala desa sekaligus berperan sebagai volunteer dan creator. Begitu juga dalam pembentukan masyarakat cyber di desa Melung, sepenuhnya adalah gagasan dari kepala desa. Pembentukan masyaralat cyber didahului dengan pembangunan sarana dan prasarana penunjangnya yaitu internet yang kemudian diikuti oleh partisipasi masyarakat dalam menggunakan internet hingga akhirnya berperan sebagai bagian dari masyarakat cyber. Upaya yang dilakukan oleh kepala desa terhadap masyarakat cyber desa Melung adalah untuk menjadikan masyarakat duta desa dalam upaya mempromosikan desa melalui berbagai media sosial. Dengan demikian pola yang diberikan oleh kepala desa akan diikuti oleh masyarakat desa atas dasar kepercayaan yang dimiliki.

Pada dasarnya suatu kehidupan sosial seperti yang ada di desa Melung terjadi atas dasar aksi dan reaksi yang jumlahnya tidak terbilang, karena terjadi setiap saat setiap kali masyarakat beraktivitas. Pihak-pihak yang terlibat dalam aksi dan reaksi ini saling menyesuaikan diri dengan pola perilaku yang kolektif. Identitas sebagai suatu desa internet atau desa cyber adalah perilaku kolektif yang coba ditanamkan oleh pemerintah desa, yang kemudian menjadi kesadaran individu.

\section{Nilai dan Norma dalam Penggunaan Media}

Keberadaan nilai dan norma di desa melung menjadi pedoman koreksi sosial saat muncul tindakan atau perbuatan tidak menyenangkan dilakukan oleh masyarakat cyber desa Melung melalui media sosial. Sama halnya dengan penyimpangan sosial yang dilakukan di dunia nyata, perilaku penyimpangan yang dilakukan di media sosial juga mendapat sanksi berdasar nilai dan norma yang berlaku.

Keberadaan nilai dan norma yang berlaku dalam penggunaan media sosial menjadikan masyarakat desa melung lebih berhati hati dalam menggunakan media sosial. Bebe- 
rapa hal terkait penggunaan media sosial masih dijaga oleh keberadaan nilai dan norma sosial, seperti penggunaan kata-kata kotor, ujaran-ujaran kebencian, adalah hal-hal yang masih dapat dikontrol oleh nilai dan norma. Selama perilaku dapat dilihat oleh anggota kelompok maka ranah nilai dan norma juga berlaku. Tetapi masalah kembali kepada individu, saat individu salah memahami tindakannya di media sosial dan masyarakat menganggapnya hal itu menyalahi nilai dan norma yang berlaku. Bagi masyarakat di desa Melung persoalan ini dianggap sebagai bagian dari cultularlag yang membutuhkan waktu untuk penyesuaian.

\section{Tindakan Proaktif dalam Pengelolan Media}

Tindakan proaktif dari anggota kelompok merupakan bagian penting bagi keberadaan masyarakat cyber desa Melung. Tindakan proaktif merupakan sikap individu yang tidak mau berdiam diri tanpa berpartisipasi dalam kelompoknya (Hasbullah, 2006, p. 16). Dalam hal ini selalu mencari jalan untuk dapat berpartisipasi di dalam kelompoknya. Keberadaan sikap proaktif warga desa Melung dalam pemgelolaan media dapat dilihat dengan berbagai konten yang bisa ditemuai di berbagai media sosial tentang desa Melung. Seperti di youtube, facebook, tweeter, ataupun di halaman website.

Pada tingkat yang paling sederhana partisipasi aktif masyarkat dalam pengelolaan media di desa Melung dapat dilihat dari kegiatan aktif di media sosial facebook. Bagi sebagian masyarakat desa Melung facebook dijadikan sebagai salah satu sarana komunikasi untuk menyebarkan informasi terkait kegiatan-kegiatan desa, khususnya informasi yang ditujukan kepada pemuda desa. Berbagai bentuk komunikasi yang dilakukan melalui media sosial oleh para pemuda di desa Melung, didalamnya terkandung semangat keaktifan dan keperdulian dalam memanfaatkan fungsi media sosial seperti yang telah di citacitakan desa.

Tindakan aktif masyarakat desa dalam penggunaan media di desa Melung merupakan kunci bagi keberlangsungan desa sebagai desa internet atau desa cyber. Masyarkat dianggap sebagai suatu proses yang dinamis, yang ditentukan oleh apa yang dilakukan oleh anggotanya (Veeger, 1993, p. 92). Dengan be- gitu saat masyarakat desa Melung masih bertindak aktif sebagai masyarkat cyber, dengan melakukan apa yang ditentukan oleh anggotanya secara terus menerus maka keberadaannya sebagai masyarkat cyber tetap terjamin. Tetapi saat hal sebaliknya terjadi, masyarakat memilih untuk membubarkan struktur sosialnya, tiap tiap angggota menentukan jalannya sendiri-sendiri, membuat peraturannya sendiri, yang akhirnya menjadikan tidak ada lagi yang tertinggal sebagai suatu kelompok maka masyarakat itu berhenti ada, dan jika terjadi di desa Melung, maka masyarakat cyber tidak lagi ada.

Dari pembahasan yang dilakukan diketahui bahwa keberadaan interenet di desa Melung memiliki berbagai implikasi terhadap kehidupan sosial masyarakat desa. Berdasarkan hasil observasi dan analisis data yang dilakukan diketahui adanya dampak positif dan negatif internet bagi kehidupan masyarakat desa.

Bentuk dampak positif yang dapat ditemui dengan adanya pembangunan jaringan internet di desa Melung antara lain: (1) Akses informasi yang luas bagi seluruh penduduk desa. Upaya pemasangan internet di desa Melung memiliki tujuan membuka akses informasi seluas-luasnya bagi seluruh penduduk desa. Masyarakat desa Melung yang sebelumnnya mengalami keterbelakangan karena terisolir dari dunia luar kini telah menjadi masyarakat yang lebih sadar terhadap berbagai informasi yang ada di dunia. (2) Rasa percaya diri penduduk desa meningkat. Rasa percaya diri merupakan efek dari dikenalnya desa Melung di sosial media dan dikenal oleh berbagai kalangan mulai dari akademisi hingga orang pemerintahan. (3) Desa lebih dikenal masyarakat luas sebagai desa internet. Keberadaan internet desa menjadi ciri khas yang disematkan kepada desa Melung.

Selain dampak positif terdapat juga dampak negative dari penggunaan media sosial oleh masyarakat desa Melung, antara lain: (1) Kesenjangan Interaksi antara orang tua dan anak. Anak memiliki dunia tersendiri dalam menggunakan media sosial. Anak-anak menjadi lebih tertutup kepada orang tua dengan media sosial yang mereka miliki. (2) Kesenjangan Informasi antarmasyarakat desa. Kesenjangan informasi terjadi sebagai akibat dari belum meratanya penggunaan media sosial pada masyarakat desa Melung. Generasi 
cyber akan memiliki kemajuan yang lebih cepat daripada mereka yang tidak menggunakan internet, terutama dalam hal informasi. (3) Perubahan perilaku anak. Pada aspek ini dampak negatif lebih ditujukan pada akibat penggunaan internet secara umum. Anak-anak yang seharusnya aktif di dunia sosial untuk bermain dan bersosialisasi menjadi lebih banyak menghabiskan waktu untuk mengakses internet dirumah.

Tabel 1. Bentuk Dampak dari Aspek Pengggunaan Media Sosial

\begin{tabular}{lll}
\hline & Dampak Positif & Dampak Negatif \\
\hline Informasi & $\begin{array}{l}\text { a. Akses informasi } \\
\text { yang luas bagi } \\
\text { seluruh penduduk } \\
\text { desa }\end{array}$ & $\begin{array}{l}\text { Kesenjangan } \\
\text { Informasi antara } \\
\text { masyarakat di desa } \\
\text { Melung }\end{array}$ \\
\hline Interaksi & $\begin{array}{l}\text { a. } \text { Rasa percaya diri } \\
\text { penduduk desa } \\
\text { meningkat }\end{array}$ & $\begin{array}{l}\text { Kesenjangan } \\
\text { Interaksi antara orang } \\
\text { tua dan anak }\end{array}$ \\
\hline Konten & $\begin{array}{l}\text { Desa lebih dikenal } \\
\text { sebagai desa internet }\end{array}$ & $\begin{array}{l}\text { Perubahan perilaku } \\
\text { anak } \\
\end{array}$ \\
& & Konflik nilai \\
\hline
\end{tabular}

Berdasarkan paparan diatas yang juga tertulis dalam tabel mengenai dampak negatif dari adanya internet dapat dianalisis bahwa munculnya dampak negatif sebagai akibat dari munculnya kebiasaan baru dan belum matangnya nilai-nilai baru pada masyarakat, keadaan ini menjadikan masyarakat kehilangan pegangan. Kondisi ini dikenal dengan masa "anomi" atau "normlessness" pada konsep Emile Durkheim (Veeger, 1993, p. 150). Masyarakat di desa Melung dengan adanya akses internet dan media sosial menjadikannya memiliki cara baru dalam berinteraksi dan bersosialisasi. Cara baru yang dilakukan dengan menggunakan media sosial tidak memiliki aturan dan tata nilai khusus. Berbeda dengan pola interaksi yang terjadi di dunia nyata, pada dunia nyata nilai-nilai dalam berinteraksi telah dipahami oleh setiap anggota masyarakat.

\section{SIMPULAN DAN SARAN}

\section{Simpulan}

Praktek penggunaan media di desa Melung: penggunaan media sosial di desa Melung masih belum merata oleh seluruh penduduk desa. Akibat dari adanya sebagian pen- duduk yang belum menggunakan media sosial memunculkan disparitas dalam penggunaan media. Disparitas penggunaan media sosial pada penduduk desa melung sebagian besar dipengaruhi oleh faktor umur dan ekonomi. Untuk penduduk yang menggunakan media sosial atau yang disebut sebagai masyarakat cyber dalam penelitian ini, keberadaan media sosial telah menjadi bagian dari kehidupan sosial atau cybersocial yang menyangkut masalah budaya, struktural dan interaksi. Berbagai kegiatan dilakukan melalui media sosial, seperti menyebarkan informasi tentang desa atau promosi, mencari informasi dan juga berinteraksi dengan pengguna media sosial lain.

Modal sosial yang dimiliki oleh masyarakat desa melung adalah kepercayaan masyarakat terhadap kepala desa. Kepercayaan masyarakat terhadap kepala desa dibangun oleh kinerja yang baik dari kepala desa, khususnya dalam program pembangunan. Berbagai program pembangunan yang terus berjalan memberikan citra yang baik terhadap sosok kepala desa. Keberadaan kepala desa yang dapat dipercaya membuat masyarakat mau mengikuti berbagai program pembangunan yang dilakukan dan turut serta aktif memberikan ide dan masukan.

Kepercayaan masyarakat terhadap kepala desa merupakan modal sosial yang berpengaruh dalam pembentukan masyarakat cyber dan pembentukan pola penggunaan media sosial di desa Melung. Kepala desa menentukan arah kebijakan tentang pembentukan masyarakat cyber, melalui pemberian pelatihan dan pemberian contoh-contoh dalam penggunaan media. Dari tindakan tersebut dapat dikatakan bahwa pola yang terbentuk dalam masyarakat cyber desa melung adalah pola penggunaan media oleh kelompok virtual tradisional. Masayrakat menggunakan media sosial atas kepentingan komunitas desa, yaitu melakukan promosi desa dan melakukan interaksi antarsesama warga desa.

\section{Saran}

Dalam upaya implementasi teknologi baru khususnya penggunaan media sosial di desa perlu melibatkan berbagai pihak, khususnya pihak-pihak yang mengerti tentang konten media mengenai manfaat dan bahaya konten media, sehingga pemahaman terhadap pemanfaatan media sosial yang ada dapat lebih maksimal. Upaya sosialisasi tentang 
pentingnya informasi yang bisa diakses melalui internet akan lebih baik jika didukung dengan disediakan juga sarana untuk mengaksesnya yaitu perangkat komputer. Dapat dilakukan dengan menyediakan komputer sebagai fasilitas umum yang diletakkan di setiap grumbul atau diletakan beberapa titik pada setiap wilayah desa. Pemerintah desa harus memberikan pembinaan, pendampingan juga pemberian contoh dalam aktivitas penggunaan media untuk dapat memperkuat pola tentang penggunaan media sosial di desa Melung, yaitu pola sebagai masyarakat cybersocial desa Melung. Pemerintah desa dapat menggunakan modal sosial yang dimiliki untuk dapat menggerakkan masyarakat agar dapat berperan aktif dalam setiap program pembangunan yang dilakukan.

\section{DAFTAR PUSTAKA}

Abdulsyani. (2007). Sosiologi, skematika, teori dan terapan. Jakarta: PT Bumi Aksara

Chen, H. \& Meng, T. (2015). Bonding, bridging, and linking social capital and self-rated health among chinese adults: Use of the anchoring vignettes technique. PLoS ONE, 10(11), 1-15

Dwiningrum, A.I.S. (2014). School resiliency and social capital of regrouping policy after Merapi eruption in the special distric of Yogyakarta of Indonesia (a case study at SD Umbulharjo 2, Sleman, Special Distric of Yogyakarta). International journal of Asian Social Science, 4(4), 510-525

Fukuyama, F. (1997). Social capital. The tanner lectures on human values. Delivered at Brasenose college, Oxford. May 12, 14, and 15, 1997 (377-484). Diakses tanggal 20 Januari 2017 dari http://libgen.me/noleech1.php?hidden $=6$ 34000\%2F63ba7bada29fc47af1f7fc5ec4 8484b1\&hidden $0=$ Francis + Fukuyama $+S$ ocial+Capital.pdf

Fukuyama, F. (2010). Trust: kebijakan sosial dan penciptaan kemakmuran. (Terjemahan Ruslani). Yogyakarta: Qalam

Gotved, S. (2006). The construction of cyber social reality. In D. Silver \& A
Massanari. Critical cyber cultural studies. New York: New York University Press.

Hanum, F. (2011). Kepemimpinan komunitas Kali code dalam menggerakkan modal sosial. Jurnal Penelitian Humaniora, 16(1), 22-44.

Hasbullah, J. (2006). Social capital: Menuju keunggulan budaya manusia Indonesia. Jakarta: MR- United Press

Junghyun, K., Robert, R., \& Wei, P. (2009). Loneliness as the cause and the effect of problematic internet use: The relationship between internet use and psychological Well-Being. Cyberpsychology \& Behavior, 12(4), 431-435

Kuan-Yu, Lin, \& Hsi-Peng, Lu. (2011). Why people use social networking sites: An empirical study integrating network externalities and motivation theory. Computers in Human Behaviour, 27, 1152-1161.

Narwoko, D., \& Suyanto, B. (2013). Sosiologi teks pengantar dan terapan. Jakarta: Kencana Prenada Media Group.

Nasrulah, R. (2016). Media sosial: Prespektif komunikasi budaya, dan Sosioteknologi. Bandung: Simbiosa Rekatama Media.

Onyx, J., \& Bullen, P. (2000). Measuring social capital in five communities. The Journal of Applied Behavioral Science, 36(1), 23-42.

Rasekhi, A. \& Angadji, J. S. (2014). The effect of social participation of social capital elements on national unity in Iran. Journal of current research in science, 2(1), 12-21.

Ritzer, G. (2014). Teori sosiologi modern dari sosiologi klasik sampai perkembangan terakhir postmodern. (Terjemahan Saut Pasaribu dkk). Yogyakarta: Pustaka Pelajar.

Strasburger, V.C., Wilson, B. J., \& Jordan, A. B. (2012). Children, adolescents, and the media. New York: Sage Publication, Inc.

Teo, T .S. H. (2001). Demographic and motivation variables associated with 
Internet usage activities. Internet research: electronic networking applications and Policy, 11(2), 125-137

Tohani, E., Sumarno, S., \& Suryono, Y. (2016). Pendayagunaan modal sosial dalam pendidikan kewirausahaan masyarakat: studi pada program pendidikan desa vokasi. Jurnal Pembangunan Pendidikan: Fondasi dan Aplikasi, 3(2), 151-166. doi: http://dx.doi.org/10.21831/jppfa.v3i2.75 $\underline{34}$.
Veeger, K. J. (1993). Relaitas sosial: Refleksi filsafat sosial atas hubungan individumasyarakat dalam cakrawala sejarah sosiologi. Jakarta: PT Gramedia Pustaka Utama.

Wichkramasinghe, V. \& Weliwitigoda, P. (2011). Benefits gained from dimension of social capital: a study of software developers in Sri Lanka. Information Technology \& People, 24(4), 394-413. 